\title{
Self-regulated learning skill as a predictor of mathematics achievement: a focus on ability levels
}

Darlington Chibueze Duru, \& Sam 0. C. Okeke

Department of Science Education, Nnamdi Azikiwe University, Awka, Nigeria

*Corresponding author: dcduru@gmail.com; samify@yahoo.com

\section{ARTICLE INFO}

Received: 22-03-2020

Received in revised: 24-05-2021

Accepted: 18-09-2021

Available online: $30-10-2021$

\section{KEYWORDS}

Mathematics;

Achievement;

Self-regulated skill;

Achievement levels;

\section{A B S T R A C T}

This paper investigated self-regulated learning skills as a predictor of students' achievement in mathematics based on ability level. The study is prediction-design research of correlational type. The subjects were 882 SSII students from the secondary schools in Owerri Education Zone of Imo State. The researchers adopted the multi-stage but simple random sampling technique to draw the sample. Two instruments were used to collect data for this study. They are the Self-regulated Learning Questionnaire (SRLQ) and Mathematics Achievement Proforma. The validity of the instruments was ensured through experts' suggestions and guidance. Single-administration reliability and Cronbach Alpha ensured the reliability of SRLQ (0.89). The data collected were analyzed using regression analysis and coefficient of determination at 0.05 alpha level with the aid of Statistical Package for Social Sciences (SPSS) version 20. The results of the study revealed that self-regulated learning skill predicts $6.0 \%$ and $4.3 \%$ respectively to the variance observed in high and low achieving students in mathematics. This prediction is significant as attested to by the regression analysis carried out $(\mathrm{p}<$ 0.05). Therefore, secondary school students should regulate their learning to increase their mathematics achievement.

\section{INTRODUCTION}

The language of mathematics has changed the way we think about the world. Most of our science and technology would have been literally unthinkable without mathematics. Clearly, mathematics is an important core subject in the secondary schools curriculum. Mathematics is a core science subject and tool for the development of any science-based discipline (Fajemidagba, Salman \& Ayinla, 2012). This particular fact has always created the impression that the learning of mathematics is exclusively reserved for science students. The truth remains that the need for the learning of mathematics has now gone beyond mathematics for only school student. But now mathematics is for life, hence it now cuts across every sphere of life, given the level of sophistry in digitalization, scientific and technological advancement as the predominant trend in our society.

Mathematics is a basic pre-requisite for the learning of any science discipline at all levels of education. It is compulsory for students in the science disciplines to have at least a credit pass in mathematics at the Senior Secondary School Certificate Examination in order to gain admission into a tertiary institution, to read science based subject or profession. For mathematics education to be meaningful, the students' academic achievement should be paramount. Academic achievement is generally regarded as the display of knowledge attained or skills developed in the school subject (Busari, 2000). Ganai and Mohamed (2013) defined academic achievement as excellence in all academic disciplines, in class as well as co-curricular activities. Ajuar (2006) opined that student's academic achievement entails successful academic progress attained through effort and skill. This is often cognitive based and measured by examination or continuous assessment. In this study, the context of academic achievement will refer to achievement of students which is measured accomplishment in teachermade-test. The students' academic achievement could be high or low; which means that it could either be good or poor. 
It is unfortunate, that in spite of the importance of mathematics, students' academic achievement worsen as years go by. Okigbo and Osuafor (2008) asserted that poor achievement of students in both external and internal examinations in mathematics have been on the increase in recent time. Several studies have drawn attention to the poor achievement of Nigerian secondary school students in mathematics (Zalmon \& Wonu, 2017; Okigbo \& Okeke, 2011). Outside Nigeria, a similar trend of poor achievement in mathematics has been observed (Olasehinde \& Olatoye, 2014).

Many variables had been identified as being responsible for the poor academic achievement of students in mathematics. Such variables include government, curriculum, examination bodies, teachers, students, parents, home, text books and psychological factors (Olaoye, 2012; Betiku in Okigbo, 2010). Having identified these factors, educators, researchers, as well as governments are keen to proffer solutions so as to reduce the poor academic achievement of students to the barest minimum. This makes all concerned researchers or educators to embark on the research to remedy the situation. The variable under focus in this study may promote lifelong learning among the students which may enhance their academic achievement in mathematics. This includes self-regulated learning skill.

The term, self-regulated learning skill can be used to describe learning that is guided by meta-cognition (thinking about one's thinking), strategic action (planning, monitoring and evaluating personal progress against a standard), and motivation to learn (Perry, Phillips, \& Hutchinson, 2006). Self-regulated learning instruction can occur in many subject areas. However, according to Metallodou and Vlachou (2007) mathematics is still perceived as a threatening area in which one requires the application of cognitive strategies. Ekuri and Offiah (2018) believed that teaching of self-regulatory skill must be instilled in the students to encourage the application of productive study skills and to build ones self-efficacy and academic motivation in the area of mathematics. Selfregulated learning skill could be important in predicting a students' academic achievement irrespective of their ability levels.

In view of academic ability level grouping, Lynch (2004) defined ability grouping as dividing students into separate classes of high, average and low achievers, that is classifying students according to their academic performance. This can best deal with individual differences in the classroom. Feldhusen (2002) noted that students of lower and average ability often flourish or become better students when the high ability level students are present and leading to competition. High ability or gifted students are needed in all classrooms in order to stimulate, motivate and inspire other students. Yaduvanshi \& Singh
(2019) grouped ability levels as low achievers (0-49\%), average achievers (50-59\%) and high achievers (70-100\%). The under achievers or low achievers, as identified by Anaso (2008) are the group of students who perform poorly in tests, examination and are also easily distracted and are less able to set about their tasks in an organized manner. Average achievers are the group of students who, according to Anaso (2008) can only record and average achievement, not because they are not capable of doing better, but partly because they cannot put in extra effort to attain better achievement. They are therefore contented to remain average. For this reason, they content themselves with the classroom learning without trying to reach out to other information. James (1991) has described the high achievers as those students who perform well in tests, assignment and examinations.

Research studies by Anaso (2008) have further shown that the more important single ingredient in achievement is a feeling of self-directed competence. Ofonime (2007) further described the high achievers as those students whose academic potentials are above the class average and their performance is described as good. All over the world, students of different abilities are found to be mixed up in the classroom settings, and yet they are exposed to the same treatment in terms of teaching, class work, home work and are required to show the same understanding. Therefore, one sees that the issues of ability level has not yet been resolved particularly in relation to students' selfregulated learning. In the context of this study, Ofonime (2007) was adopted and classified ability levels; $0-49 \%$ as low achievers while $65-100 \%$ as high achievers without considering average achievers. Hence this study is poised to find out the extent to which self-regulated learning skill predict students' achievement in mathematics focusing on ability levels.

\section{Research Questions}

The study provides answers to the following research questions:

1. To what extent does the self-regulated learning skill significantly predict high achieving students' mathematics achievement?.

2. To what extent does the self-regulated learning skill significantly predict low achieving students' mathematics achievement?.

\section{METHODS}

The study is a prediction design research of correlational type. This is a higher order correlational research design that extends the least-square association principle to the study of relationship between one dependent variable and two or more independent variables. The subjects were 882 SSII students from the secondary schools in Owerri Education Zone of Imo State. The researchers adopted the 
multi-stage but simple random sampling technique to draw the sample. Two instruments were used to collect data for this study. They are: (i) Self-regulated Learning Questionnaire (SRLQ) (ii) Mathematics Achievement Proforma (MAP). The validity of the instruments was ensured through experts' suggestions and guidance. A single-administration reliability and Cronbach Alpha ensured the reliability of SRLQ (0.89). The data collected were analyzed using regression analysis and coefficient of determination at 0.05 alpha level with the aid of Statistical Package for Social Sciences (SPSS) version 20.

\section{RESULTS AND DISCUSSION}

This section deals with the presentation, interpretation and analysis of data. The data presented in form of tables provided answers to the research questions.

The results in Table 1 revealed that self-regulated learning skill predicts $6.0 \%$ to the variance observed in high achieving students in mathematics. From the result of the regression analysis self-regulated learning skill significantly predicts high achieving students' mathematics achievement. This is because the p-value (Sig. $=0.000$ ) is less than the 0.05 level of significance.

The results in Table 2 revealed that self-regulated learning skill predicts $4.3 \%$ to the variance observed in low achieving students in mathematics. From the result of the regression analysis self-regulated learning skill significantly predicts low achieving students' mathematics achievement. This is because the p-value (Sig. $=0.000$ ) is less than the 0.05 level of significance.

Table 1. Significant prediction of predictor variable to mathematics achievement for high achieving students

\begin{tabular}{lccccc}
\hline \multicolumn{1}{c}{ Variables } & $\mathbf{N}$ & $\mathbf{R}$ & $\boldsymbol{R}^{2}$ & $\mathbf{F}$ & Sig. \\
\hline Self-regulated learning skill & 42 & .245 & .060 & 1.402 & .000 \\
Mathematics Achievement & 42 & & & & \\
\hline
\end{tabular}

Table 2. Significant prediction of predictor variables to mathematics achievement for low achieving students

\begin{tabular}{lccccc}
\hline \multicolumn{1}{c}{ Variables } & $\mathbf{N}$ & $\mathbf{R}$ & $\boldsymbol{R}^{2}$ & $\mathbf{F}$ & Sig. \\
\hline $\begin{array}{l}\text { Self-regulated learning } \\
\text { skill }\end{array}$ & 704 & .209 & .043 & 31.905 & .000 \\
Mathematics Achievement & 704 & & & & \\
\hline
\end{tabular}

\section{Discussions}

The findings of this study revealed that self-regulated learning skill predicts $6.0 \%$ to the variance observed in high achieving students in mathematics. While, selfregulated learning skill predicts $4.3 \%$ to the variance observed in low achieving students in mathematics. From the result of the regression analysis self-regulated learning skill significantly predicts both high and low achieving students' mathematics achievement. This indicates that other factors influenced students' achievement in mathematics other than self-regulated learning skill. However, an improvement in self-regulated learning skill would lead to increased students' mathematics achievement irrespective of their ability levels. Mutweleli (2014) reported that academic achievement is unpredictive of self-regulated learning skill. This goes to show that even though self-regulated learning skill related positively with students' achievement in mathematics, the relationship is significant. This means that one can use knowledge of students' self-regulated learning skill to predict what their achievement in mathematics would likely be.

This study suggests the need to help secondary school students overcome every problem associated with selfregulated learning skill. Such help and effort will go a long way to increasing students' achievement in mathematics and at the same time help students to belief in their own learning capability. Ekuri and Offiah (2018) investigated self-regulatory attribute and academic performance in mathematics among secondary school students. The results revealed that self-regulatory attribute variables had a significant relationship with academic performance in mathematics. In a similar study, Olasehinde and Olatoye (2014) investigated self-regulation as a determinant of senior secondary school students' achievement in science. The result revealed that self-regulation accounted for $1.0 \%$ of the total variance in science achievement. There was a positive and significant relationship between science achievement and self-regulation. More so, Busari (2013) carried a quantitative study investigating the relationship between self-regulated learning, motivation, anxiety and achievement in mathematics. Data analyses revealed that significant contributions are made by self-regulation, on mathematics scores of the participants.

\section{CONCLUSION}

The results obtained showed that mathematics achievement had significant correlations with all the three independent variables. The results also revealed that mathematics achievement of the participants correlated positively with the three predictor variables. The results of this study also indicate that self-regulation was the most potent contributor to academic achievement. This finding underlies the importance of self-regulation over the course of developing expertise in a domain, such as mathematics.

\section{RECOMMENDATION}

Based on the findings of the study, the following recommendations are made: 1 ) Students should regulate their learning so as to increase their mathematics achievement, 2)There should be continuous public enlightenment campaign on the importance of selfregulated learning skill. This enlightenment campaign should be carried out at all the government levels, 3) There is need to help secondary school students overcome every problem associated with self-regulated learning skill. Such help and effort, by school guidance counselors, school 
authorities, parents and teachers, will go a long way to increasing students' mathematics achievement and at the same time help students to reduce the stress caused by failure.

\section{Acknowledgement}

The authors would like to thank all parties who have assisted in the research and writing of this manuscript so that it deserves to be widely published to the academic community.

\section{REFERENCES}

Ajuar, H.N. (2006). Meta- analysis of research findings on environment and students-achievement in science. Unpublished Doctoral Dissertation, University of Nigeria Nsukka.

Anaso, J. N. (2008). Effect of class-size on the academic achievement and retention of different ability groups among senior secondary school chemistry students. PhD Dissertation A.B.U. Zaria.

Busari A. 0. (2013). Assessing the relationship of self-regulation, motivation and anxiety on mathematics achievement of elementary school children in south -western Nigeria. An International Multidisciplinary Journal, 7 (3), 110-126

Busari, A.O. (2000). Stress inoculation training and selfstatements monitoring techniques in the reduction of test anxiety among adolescent underachievers in Ibadan metropolis, Nigeria. Unpublished Ph.D. thesis, University of Ibadan.

Ekuri, E.E \& Offiah, C.I (2018). Self-regulatory attributes and academic performance in mathematics among secondary school students in Enugu Education Zone, Enugu State. International Journal of Scientific Research in Education. 11(3), 455-466

Fajemidagba, M., Salman, M. \& Ayinla, J. (2012). Effect of teachers' instructional strategy pattern on senior school students performance in mathematics world problem in Ondo. Nigeria. Journal of Education and Practice, 3(7), 159-168

Feldhusen, J.F (2002). Guidelines for grade advancement of precocious children. Roeper Review, 24 (3), 25-27.

Ganai, M. Y., \& Muhammed, A. (2013). A comparative study of adjustment and academic achievement of college students. Journal of Education Research and Essays, 1(1), 5-8

Lynch, K. (2004). Research and theory on equality in education. In M. Hallinan, ed., Handbook of sociology of education (New York: Plenum Press), 85-105.
Metallidou, P., \& Vlachou, A. (2007). Motivational beliefs, cognitive engagement, and achievement in language and mathematics in elementary school children. International Journal of Psychology, 42(1), 2-15.

Mutweleli S. M. (2014) Academic motivation and self-regulated learning as predictors of academic achievement of students in public secondary schools in Nairobi, Kenya. Unpublished doctoral dissertation. Kenyatta University.

Ofonime F.N. (2007). Effect of constructivist-based instructional model on senior secondary students' achievement in biology. Proceedings of the 50th annual conference of the Science Teachers Association of Nigeria, 98-101.

Okigbo, E.C. \& Okeke, S.O.C, (2011). Effects of games and analogies on students-interest in mathematics. Journal of the Science Teachers Association of Nigeria, 46(1), 101-112.

Okigbo, E.C. \& Osuafor. A.M. (2008). Effect of using mathematics laboratory in teaching mathematics on the achievement of mathematics students. Journal of Education of Research and Review, 3(8), 257-261.

Okigbo, E.C. (2010). Comparative effectiveness of mathematical game and instructional analog as advance organizers on achievement, retention and interest in mathematics. Unpublished doctoral dissertation, Nnamdi Azikiwe University, Awka, Nigeria.

Olaoye A. A. (2012). Effect of self-regulated learning (SRL) and conventional strategies on students' performance in mathematics. British Journal of Science: 4 (1) 169 -176

Olasehinde, K.J \& Olatoye, R.A (2014). Self-regulation and peer influence as determinants of senior secondary school students' achievement in science. Mediterranean Journal of Social Sciences. 5(7), 374-380.

Perry, N.E., Phillips, L., \& Hutchinson, L.R. (2006). Preparing student teachers to support for self-regulated learning. Elementary School Journal, 106, 237-254.

Sangeeta, Y \& Singh, S (2019). Fostering achievement of low-, average, and high-achievers-students in biology through structured cooperative learning (STAD Method). Hindawi Education Research International, Volume 2019, Article ID 1462179,10 pages.

Zalmon, I. G. \& Wonu, N. (2017). Comparative analysis of student mathematics achievement in West African Senior Secondary Certificate Examination in Nigeria. European Journal of Research and Reflection in Educational Science, 5 (1), 24-37. 